\title{
Nepominutelný dědic a jeho právo na povinný díl
}

\section{Forced Heir and his Right to Inherit the Forced Share}

\author{
Iveta Talandová*
}

\begin{abstract}
Abstrakt
Nepominutelný dèdic je klasickým pojmem soukromého práva, a jak, je ze samotnébo pojmenováni patrné, jde o osobu, která nemá být prì dědèni opomenuta. Na tohoto nepominutelnébo dédice by mél quistavitel v prípadě pořzzeni pro prípad smrti pamatovat a zanechat mu alespoñ jeho zákonem stanovený povinný díl. Současná úprava výsí povinnébo dilu oproti predchozí úpravě razantně zkerátila, a to ažn na takrkea zanedbatelnou hodnotu, pričemžv rámci rekodifikeačni komise bylo diskutováno i o úplném zrušeni tohoto institutu. V odborných i profesnich kruqích se v souvislosti s tímto otevrely diskuze, zda je úprava povinnébo dilu jestě zapotrebí. Následujici text, kterýje vènován historickému vývoji tohoto institutu, soüasné uipravěv občanském áakoniku, a také iustavnèprávnim aspektuim tohoto institutu, by mèl prinést dalš́ nábled do wedené diskuze.
\end{abstract}

\section{Klíčová slova}

Dédické právo; nepominutelný dèdic; právo na povinný díl.

\begin{abstract}
Forced heir is classical concept of private law, and as the very name shows, it is a person who should not be overlooked when inheriting. Testator should, in the case of acquisition in case of death of the forced heir to remember and leave him at least the forced share regulated by law. The current legislation a mandatory part dramatically shortened and at almost negligible value compared with the previous legislation, whereas in the recodification committee also discussed on the complete abolition of this institute. The expert and professional circles in connection with this open discussion about whether the modification of forced heir work still needed. Another text, which is devoted to the historical development of this institute, its current form in the Civil Code and the constitutional aspects of this institute can bring to the discussion a new outlook.
\end{abstract}

\section{Keywords}

Inheritance Law; Forced Heir; Forced Share.

„Proto dèdické právo nesmi preblédnouti, že člověke zpravidla proto pracuje, proto se namáhá, aby získal hmotné odmèny, a aby hodnoty nastrádané odevżdal tèm, ke keterým má ư̌š́ vątaby príbuzenství, prátelství, lásky." 1

E. Svoboda

\footnotetext{
* Mgr. Iveta Talandová, Katedra soukromého práva a civilního procesu, Univerzita Palackého v Olomouci; asistentka soudce Okresního soudu v Olomouci / Department of Private Law and Civil Procedure, Faculty of Law, Palacký University, Olomouc, Czech Republic; Assistant Judge of the District Court in Olomouc / E-mail: iveta.talandova@gmail.com

1 SVOBODA, Emil. Dédické právo. Praha: Československý kompas, 1946, s. 7.
} 


\section{Úvod}

Nepominutelný dědic je klasickým pojmem soukromého práva, a jak je ze samotného pojmenování patrné, jde o osobu, která nemá být při dědění opomenuta. Na tohoto nepominutelného dědice by měl zůstavitel $\mathrm{v}$ př́padě pořízení pro případ smrti pamatovat a zanechat mu alespoň jeho zákonem stanovený povinný díl. Současná úprava výši povinného dílu oproti předchozí úpravě razantně zkrátila, a to až na takřka zanedbatelnou hodnotu, přičemž v rámci rekodifikační komise bylo diskutováno i o úplném zrušení tohoto institutu. ${ }^{2} \mathrm{~V}$ odborných i profesních kruzích se v souvislosti s tímto otevřely diskuze, zda je úprava povinného dílu ještě zapotřebí. Následující text, který je věnován historickému vývoji tohoto institutu, současné úpravě v občanském zákoníku, a také ústavněprávním aspektům tohoto institutu, by měl přinést další náhled do uvedené diskuze.

\section{Pořizovací volnost vs. rodinná solidarita}

$\mathrm{V}$ rámci historického vývoje dědického práva se do střetu dostávají dva protichůdné principy, a to princip pořizovací volnosti, který klade důraz na autonomii vůle zůstavitele, jehož opakem je princip rodinné solidarity, který preferuje rodinné dědické nástupnictví. ${ }^{3}$ Princip rodinné solidarity se projevuje především ve výčtu osob v dědických skupinách, když přednostně jsou za dědice ustanoveny nejbližší osoby zůstavitele, tedy potomci, manželka, manžel či rodiče. ${ }^{4}$ Aby došlo k vyvážení ochrany nejbližších osob $\mathrm{v}$ př́padě, kdy se zůstavitel rozhodne o svém majetku pořídit pro prrípad smrti, vznikl institut nepominutelného dědice, nebot' Porizovaci svoboda nesmi prejíti v porizovací zvinili ${ }^{5}$ Z následujícího textu, který stručně popisujíce historický vývoj nepominutelného dědice, jsou patrné odlišné př́stupy $\mathrm{k}$ tomuto institutu, které se odvijí právě od toho, jakému principu dal ten který občanský zákoník přednost.

2 BEDNÁř, Václav. Dědické právo v novém občanském zákoníku. Obchodni právo, 2012, roč. 21, č. 5, s. $162-171$

3 E. Tilsch jej nazývá principem nucenosti, který má objektivní charakter, proti kterému stojí princip volnosti, jehož charakter je subjektivní. O. Horák pak princip nucenosti nazývá výstižněji jako princip rodinné solidarity a princip volnosti jako princip pořizovací volnosti. TILSCH, Emanuel. Rakouské právo dědické. Praha: Všehrd, 1904, s. 18; HORÁK, Ondřej. Tzv. nepominutelný dědic v novém občanském zákoníku. Právní roẓledy, 2014, roč. 22, č. 11, s. 38.

4 Je spravedlivo, aby byli dèdici ti lidé, se kterými žil zuistavitel ve stycich nejužšich. Jeho dèti-protože povinností toho, kedo dèti zplodil, jest, aby se postaral o jejich prǐstí osudy. Žena, protožze často ani nelz̨e rozlisiti, kolik jejího vlastního pričinèní jest uloženo v majetku mužově, jeho vžniku i zachování, i proto, že se dloubým manželstvím a praci v rodině stává méně zpiisobilou k samostatné práci výdèlečné, je sociálnè slabši. Mǔ̆, protože sotva kedo určí, kolik práce vynaložil, aby jeji majetek zachoval a rozmnožil. Rodiče, kterým člověke děkuje za své vychováni a prípravu na vlastni práci životni. SVOBODA, Emil. Dédické právo. Praha: Československý kompas, 1946, s. 8.

5 SVOBODA, Emil. Dédické právo. Praha: Československý kompas, 1946, s. 9. 


\section{Obecný zákoník občanský}

Obecný zákoník občanskýc podporoval autonomii vưle zůstavitele a ponechával zůstaviteli široké možnosti, jak pořídit o svém majetku pro případ smrti (závět', dědická smlouva, odkazy). Zůstavitel si tak mohl za dědice či odkazovníka zvolit kteroukoliv osobu, a to i mimo zákonnou dědickou posloupnost. Jediné omezení představovaly nejbližší osoby zůstavitele, které zákon označoval za nepominutelné dědice. ${ }^{7} \mathrm{Na}$ tyto osoby zůstavitel musel, $v$ prrípadě že činil pořízení pro případ smrti, pamatovat a zanechat jim jejich zákonem stanovený povinný díl. Povinný díl nepominutelných dědiců byl však zároveň pod ochranou dalších institutů (především vrácení daru na povinný díl) ${ }^{8}$ tak, aby nemohl být zůstavitelem obcházen jednáním inter vivos. Mezi nepominutelné dědice patřily děti zůstavitele, ${ }^{9}$ a nebylo-li jich, tak rodiče zůstavitele. ${ }^{10}$ Děti byly zařazeny mezi nepominutelné dědice $z$ důvodu, že zůstavitel, který tyto děti zplodil, měl za ně i odpovědnost, a bylo tak jeho povinností postarat se o jejich budoucnost. ${ }^{11}$ Rodiče pak z do̊vodů jejich zajištění na stář́i. ${ }^{12}$

6 Císařský patent č. 946/1811 JGS z 1. června 1811 (dále jen „obecný zákoník občanskýc).

7 Je třeba podotknout, že již v této době byl kritizován pojem „nepominutelný dědic“, nebot’ tato osoba neměla dědický nárok, ale pouze nárok obligační spočívající ve vyplacení povinného dílu. E. Svoboda pak navrhoval zavést termín „nepominutelný čekatel“, který je zcela jistě výstižnějšíi, nebot’ jde skutečně o osobu, která čeká na svi̊j díl z pozůstalosti, a toto právo je nepominutelné. Tato otázka byla diskutována také při rekodifikačních snahách, když důvodová zpráva k osnově občanského zákoníku z roku 1931 sama uvádí, že termín „nepominutelný čekatel“ by byl vhodnější, ne však úplně přesný, a proto ve svém návrhu stále používá spojení „nepominutelný dědic“. Vládní návrh z roku 1937 se pak naopak pojmu „,nepominutelný dědic“ zastává, nebot’ slovo „čekatel“, jak uvádí důvodová zpráva, se nezdá být vhodné, nebot' je to označení pro osobu značně se lišící od osoby, která má právo na povinný díl. A tak se i v návrhu znovu objevil již dř́ve kritizovaný pojem „,nepominutelný dědic“, přestože jak sama důvo-

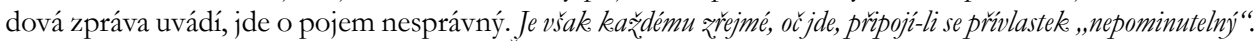
SVOBODA, Emil. Dédické právo. Praha: Československý kompas, 1946, s. 72; SVOBODA, Emil (ed.). Dédické právo: návrh subleomitétu pro revisi občanského zákonika pro Ceskoslovenskou republiku. 2. vyd. Praha: Ministerstvo spravedlnosti, 1924, s. 68; Dîvodová zpráva k. vládnimu návrbu obćanskébo qákoníku z roku 1937. Komentár k blave 21 ( 574 aそ̌ 601). Dostupné na <http://senat.cz/informace/z_historie/tisky/4Vo/ tisky/T0425_24.htm>.

8 Vrácení daru na povinný díl spočívalo $\mathrm{v}$ tom, že pokud pozůstalost nestačila $\mathrm{k}$ úhradě povinného dílu, musel ten jehož dar byl do pozůstalosti započten, vrátit z daru tolik, kolik je třeba $\mathrm{k}$ doplnění povinného dílu.

9 Za děti byly považovány i vnuci, či pravnuci, pokud jejich předchůdci již nežili. $\int 763$ OZO.

10 Za rodiče byly rovněž považováni i prarodiče, pokud jejich předchůdci již nežili. $\int 763$ OZO.

11 SVOBODA, Emil. Dédické právo. Praha: Československý kompas, 1946, s. 8.

12 Manžel či manželka nebyli mezi nepominutelné dědice zařazeni, nebot' jejich ochrana po smrti zůstavitele byla zajištěna jinak, a to tak že jim bylo po dobu vdovství (6 týdnů) z pozůstalosti poskytováno slušné zaopatření, pokud si jej tato osoba nemohla zajistit sama z vlastních prostředků, a pokud by tento náklad na slušné zaopatření nebyl zajištěn prostřednictvím zákonného dědického podílu nebo jiným způsobem jednání inver vivos nebo mortis causa. Slušné zaopatření nemělo uhradit jen nejnutnější potřeby (srov. pozn. 15 o nutné výživě), ale mělo zajistit průměrný životní standard. ROUČEK, František, SEDLÁČEK, Jaromír. Komentár k československému obecnému حákoniku občanskému a občanské právo platné na Slovensku a v Podkarpatské Rusi. Díl III (J 531 - 858). Praha: V. Linhart, 1935-1937, s. 483-484. 
Dětem se bez ohledu na věk měla dostat alespoň $1 / 2$ z toho, co by jim připadlo dle zákonné dědické posloupnosti, rodičům pak alespoň $1 / 3$ z toho, co by obdrželi dle zákonné dědické posloupnosti. Výši takto zákonem stanoveného povinného dílu bylo možné ještě zkrátit prostřednictvím započtení. ${ }^{13}$

Na povinný díl bylo nahlíženo jako na pohledávku nepominutelného dědice vưči dědicům (odkazovníkům). To znamenalo, že v případě kdy se nepominutelnému dědici jeho povinný díl nedostal, popř́ípadě byl zkrácen $\mathrm{v}$ důsledku zůstavitelova pořízení pro případ smrti, nemohl nepominutelný dědic žádat konkrétní podíl z pozůstalosti, ale měl nárok na výplatu povinného dílu v penězích. Povinnost $\mathrm{k}$ dorovnání povinného dílu měli dědicové (popřípadě odkazovníci).

Právo na povinný díl však nepředstavovalo právo absolutní, nebot' byly dány zůstaviteli možnosti, jak právo na povinný díl nepominutelného dědice prostřednictvím vydědění zčásti nebo zcela vyloučit. Nepominutelný dědic mohl být ze svého práva na povinný díl vyloučen i na základě zákona v prŕpadě, že byl dědicky nehodný (nezpůsobilý) a zůstavitel mu čin zakládající dědickou nehodnost neodpustil. ${ }^{14} \mathrm{~V}$ úvahu prípadala také možnost, že se nepominutelný dědic sám zřekl svého povinného dílu smlouvou se zůstavitelem. Avšak ve všech těchto př́padech, kdy se nepominutelnému dědici jeho povinný díl zčásti nebo zcela nedostal, měl tento nepominutelný dědic nárok alespoň na nutnou výživu. ${ }^{15}$

Lze říci, že obecný zákoník občanský balancoval mezi principem pořizovací volnosti a principem rodinné solidarity velice dobře, protože na jednu stranu dával zůstaviteli široké možnosti co do rozhodování o jeho majetku pro př́ípad smrti, zároveň však nezapomínal na nejbližší osoby, resp. nepominutelné dědice, jejichž povinný díl byl dostatečně chráněn tak, aby nemohl být zkrácen ani jednáním inter vivos (započtení daru, vrácení daru na povinný díl) ani mortis causa (vyplacení povinného dílu v penězích). Ve stejném smyslu navázaly i meziválečné návrhy z roku 1931 a 1937.

\section{Občanský zákoník z roku 1950}

Občanský zákoník z roku $1950^{16}$ zcela popřel úpravu obsaženou v obecném zákoníku občanském a v návrzích z roku 1931 a 1937, a to nejenom v oblasti dědického práva. Upřednostněno bylo dědění ze zákona, které mělo utvrzovat rodinné svazky a hospo-

$13 \int 787$ a násl. obecného zákoníku občanského.

14 Pro důvody dědické nehodnosti mohl být i vyděděn.

15 Nutná výživa byla taková výživa, která byla nezbytná k životu. Nepominutelnému dědici prríslušela jen tehdy, pokud se mu nedostávala a nesměla převýšit částku povinného dílu (viz pozn. 12). ROUČEK, František, SEDLÁČEK, Jaromír. Komentár k československému obecnému zákoniku občanskému a občanské právo platné na Slovensku a v Podkarpatské Rusi. Díl III (』 531-858). Praha: V. Linhart, 1935-1937, s. 484.

16 Zákon č. 141/1950 Sb. ze dne 25. října 1950, známý také jako střední občanský zákoník. Dále jen jako „občanský zákoník 1950“. 
dářskou základnu rodiny. ${ }^{17,18}$ Oproti tomu závět' byla označena za prostředek, který zasahuje do dědického práva, a který vyvolává důsledky, které by jinak nenastaly. Proto byl zůstavitel ve své vůli značně omezen, aby prostřednictvím závěti nemohl porušit základní funkci dědického práva, kterou je posílení rodinných vztahů. Převzata nebyla ani dědická smlouva, a to s odůvodněním, že podvazuje pro budoucnost zůstavitelovu pořizovací svobodu.

Občanský zákoník z roku 1950 mezi nepominutelné dědice mimo děti zůstavitele zahrnoval taktéž rodiče či prarodiče, pokud byli v době zůstavitelovy smrti v nouzi a práce neschopní. ${ }^{19}$ Nově se výše povinných dílu u potomků odvíjela od jejich věku, ${ }^{20} \mathrm{když}$ u nezletilých představovala tolik, kolik činí cena celého jejich zákonného podílu, u zletilých potomků a rodičů pak byla cena povinného dílu 3/4 toho, kolik by jim náleželo při dědění ze zákona. ${ }^{21,}{ }^{22} \mathrm{~V}$ př́padě, že zůstavitel, který pořídl závět, nedodržel výše těchto podílu, byla závět' v této části neplatná. ${ }^{23}$

Zcela se tak změnilo dosavadní pojímání povinného dílu, jako obligačního práva vůči dědicům. Nově šlo o subjektivní dědické právo nepominutelného dědice, jehož nedodržení mělo za následek zneplatnění části nebo i celé závěti. Tato neplatnost byla jak v teorii tak praxi posouzena jako relativní, ${ }^{24}$ které se musel nepominutelný dědic dovolat. ${ }^{25} \mathrm{Ob}$ čanský zákoník z roku 1950 tak především chránil nepominutelné dědice, a to na úkor

17 Institut dědění ze zákona byl výrazem zájmu společnosti na tom, aby i v oboru dědického práva jednot-

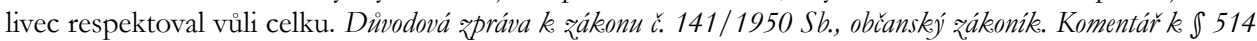
a 515. Dostupné na <http://psp.cz/eknih/1948ns/tisky/t0509_16.htm>.

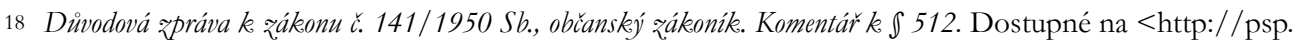
cz/eknih/1948ns/tisky/t0509_16.htm>.

19 „Práce neschopni“ byl takový stav, v němž neměl rodič dostatečné prostředky na úhradu nákladů osobní potřeby přiměřené svým poměrům. HOLUB, Robert. Komentár k občanskému zákoníku - právo dédickée. Praha: Orbis, 1957, s. 181.

20 Rozlišení velikosti podílu dle zletilosti potomků bylo převzato ze sovětské úpravy a setrvalo v naší úpravě dodnes.

$21 \int 551$ občanského zákoníku 1950.

22 I když zákon hovořil o „ceně povinného dílu“ neznamenalo to, že měl nepominutelný dědic nárok na peněžní částku vůči zákonným dědicům. Zákon tím myslel hodnotu dědického podílu, na jakou má nepominutelný dědic nárok. HOLUB, Robert. Komentár k občanskému zákoníku - právo dédické. Praha: Orbis, 1957, s. 188.

$23 \int 551$ občanského zákoníku 1950.

24 Opačný názor zastával K. Plank, který se přikláněl k tomu, aby dané jednání bylo posuzováno jako absolutně neplatné, nebot' účelem je v tomto př́padě chránit dědické právo těch osob, které jsou odkázány na zůstavitele, a umožnit jim dědit ze zákona i přesto, že byly v závěti bezdůvodně opomenuty. PLANK, Karol. Dédičské právo. Bratislava: Slovenské vydavatel'stvo politickej literatúry, 1954, s. 141.

25 Výjimku představovaly případy, kdy byl nepominutelný dědic nesvéprávný, a bylo nutné soudní schválení prohlášení jeho zákonného zástupce o platnosti závěti. $V$ takovém př́padě se teorie i praxe přikláněla k absolutní neplatnosti takové závěti. HOLUB, Robert. Komentár k občanskému zákoníku - právo dédické. Praha: Orbis, 1957, s. 181. 
autonomie vůle zůstavitele. $V$ této úpravě tak byl výrazně upřednostněn princip rodinné solidarity.

\section{Občanský zákoník z roku 1964}

Občanský zákoník z roku $1964^{26}$ ideově navázal na občanský zákoník z roku 1950. Stále upřednostňoval dědění ze zákona oproti dědění ze závěti, ${ }^{27}$ což se projevovalo i v úpravě povinného dílu. Nově však byli za nepominutelné dědice ${ }^{28}$ ustanoveni pouze potomci zůstavitele, kteří zůstali rozdělení na nezletilé, kterým se mělo dostat alespoň tolik, kolik činil jejich dědický podíl ze zákona a zletilé, jejichž povinný díl zůstal až do roku 1990 na 3/4 jejich dědického podílu, poté byl novelou č. 509/1991 Sb. snížen na 1/2. Díky zúžení okruhu nepominutelných dědiců měl zůstavitel teoreticky větší možnost pořídit o svém majetku podle svého vlastního uvážení. Na druhou stranu byla velikost povinného dílu u nepominutelného dědice natolik velká, že v případě, kdy byl zůstavitel bez manžela, a měl pouze jednoho nezletilého potomka, musel v případě pořízení závěti zanechat veškerý majetek právě jemu. Pokud povinný díl nepominutelného dědice zůstavitel v závěti nerespektoval, a nepominutelný dědic své právo na povinný díl uplatnil, mohlo dojít $\mathrm{k}$ zneplatnění části, poprrípadě i celé závěti (šlo-li např́klad o povinný díl výše uvedeného nezletilého potomka). Tato neplatnost byla posuzována jako relativní, které se musel nepominutelný dědic dovolat.

Zároveň bylo vypuštěno posledních několik institutů z obecného zákoníku občanského, které občanský zákoník z roku 1950 zachoval (žreknutí se dědického práva, klasické odkazy a až do roku 1981 bylo vypuštěno i samotné vydědění, které bylo doplněno $\mathrm{až} \mathrm{v} \mathrm{rámci} \mathrm{novelizace).} \mathrm{Princip} \mathrm{rodinné} \mathrm{solidarity} \mathrm{tak} \mathrm{byl} \mathrm{ještě} \mathrm{posílen,} \mathrm{a} \mathrm{to} \mathrm{vše} \mathrm{na} \mathrm{úkor}$ autonomie vůle zůstavitele.

Socialistická úprava obsažená v občanském zákoníku z roku 1964 se stala po roce 1989 nevyhovující, místo zcela nového kodexu se však prristoupilo k novelizaci tohoto zákona a takto byl občanský zákoník zachován až do účinnosti nového občanského zákoníku v roce 2014. Díky tomuto byl občanský zákoník často terčem kritiky, a to především pro svou úpravu dědického práva, jak uvádí V. Bednář: „V kontextu celého platného občanského zákoníku prisobi úprava dèdického práva jaksi nepatrìnnè, chtèlo by se rúci, že je takovým ošklivým káčátkem. Je třba si uvédomit, že se jedná o jednu z. nejvice zanedbaných části občanskébo

26 Zákon č. 40/1964 ze dne 25. února 1964, dále jen „občanský zákoník 1964“.

27 Dìvodová zpráva k zákonu č. 40/1964 Sb. Komentár k. Hlavě treti: Déděni zue závèti. Dostupné na <http://psp. cz/eknih/1960ns/tisky/t0156_13.htm>.

28 Zákon sice pojem „nepominutelný dědic“ nepoužívá, ale lze jej z jeho úpravy vyvodit, což je trošku paradoxní, nebot' právě v zákoně z roku 1964 (i v zákoně z toku 1950) má nepominutelný dědic opravdu postavení dědice, nikoli pouze věritele dědiců, jak tomu bylo v obecném zákoníku občanském. 
zákoníku. "29 Konkrétně pak byly kritizovány všechny změny v dědickém právu, které byly zavedeny od roku 1950, a to strohá úprava, omezená vưle zůstavitele, právo nepominutelných dědiců na povinný díl in natura, chybějící instituty jako je zřeknutí se dědického práva, omezená práva věritelů zůstavitele atd. V. Bednář ve svém článku z roku 2010 shrnuje, že stávajici úprava je nedostatečná, v rozporu s obecnou zásadou testovaci svobody, a v konečném dìsledku řivot spiše komplikuje. "30,31

\section{Občanský zákoník}

Současná úprava ${ }^{32}$ se v mnoha ohledech vrací ke klasické úpravě dědického práva známé z obecného občanského zákoníku a návrhů občanských zákoníku z roku 1931 a 1937.33 Mezi nepominutelné dědice patři dle současného občanského zákoníku děti zůstavitele, a nedědí-li, pak jejich potomci. ${ }^{34}$ Těmto osobám náleží právo na povinný díl, který v současné době představuje u nezletilého alespoň $3 / 4$ jeho zákonného dědického podílu a u zletilého pouhou 1/4 jeho zákonného dědického podílu. Oproti předchozí úpravě tak došlo k razantnímu snížení povinných dílů (především u zletilých dětî) s cílem, aby zůstavitel mohl o svém majetku rozhodovat především podle vlastní vůle. Změna nastala $\mathrm{i}$ v celkovém pojetí nepominutelných dědiců, zatímco v předchozí úpravě měli stejné postavení jako ostatní dědicové (povinný díl nabývali jako dědictví a odpovídali tedy i za dluhy zůstavitele), v současné úpravě je povinný díl pojímán jako pohledávka, kterou má nepominutelný dědic vůči dědicům. $V$ případě, kdy zůstavitel nezanechá nepominutelnému dědici jeho povinný díl, zůstane závět' stále v platnosti. Institut nepominutelného dědice a jeho práva na povinný díl lze tak za současné úpravy spíš vnímat jako varovné signály, na které zůstavitel, který má děti, narazí ve chvíli, kdy chce pořídit závět'. Tyto varovné signály dávají zůstaviteli na vědomí, že si nemůže se svým majetkem nakládat zcela bez omezení, a že musí brát ohled na své potomky, za které nese odpovědnost. Tyto signály však mají pouze doporučující funkci, protože v případě, že je zůstavitel ignoruje, nemusí mít obavy, že by jeho vůle zůstala nenaplněna. Pouze přenese povinnost k vyrovnání povinného dílu na dědice. ${ }^{35}$ Nakolik tak samotný zůstavitel svou

29 BEDNÁř, Václav. Nepominutelný dědic. In: HAVEL, Bohumil, PIHERA, Vlastimil. Soukromé právo na cestě. Eseje a jiné testy k. jubileu Karla Eliáše. Plzeň: Aleš Čeněk, 2010, s. 17.

30 Tamtéž.

31 Ani o současné úpravě dědického práva však z pohledu notářů či běžných občanů nelze říci, že by život ulehčovala.

32 Zákon č. 89/2012 Sb. ze dne 3. února 2012, dále jen „občanský zákoník“.

33 Z 246 dědickoprávních ustanovení občanského zákoníku se u 191 stal inspirací vládní návrh z roku 1937 (celkově je tedy podobnost této úpravy 78 \%). DADUOVÁ, Martina, HORÁK, Ondřej. Nové dědické právo a meziválečná rekodifikace. Ad Notam, 2016, č. 1, s. 12.

34 Současný návrat k pojmu „nepominutelný dědic“ není úplně nešt’astnější (viz poznámka 4).

35 Tímto se současná úprava výrazně liší od úpravy předchozí, nebot' v ní mělo opomenutí nepominutelného dědice za následek neplatnost závěti. 
vůli podrobí zákonu, je zcela na něm, a nelze tedy hovořit o absolutním omezení vůle zůstavitele (a to i vzhledem k možnosti zkrácení či omezení povinného dílu prostřednictvím vydědění, započtením na povinný díl či zřeknutí se povinného dílu).

Současná úprava se snaží v úpravě nepominutelných dědiců a povinného dílu přiblížit obecnému zákoníku občanskému, avšak za účelem chránit co nejvíc vưli zůstavitele se již nepovedlo ochránit zájmy nepominutelných dědiců, což se projevilo ve zmenšení povinných dílů, a především v nezakotvení institutu vrácení daru na povinný díl. Současné tendence tak mírí k tomu tento institut co nejvíce oslabit, tak aby byl co nejvíc podpořen princip pořizovací volnosti. Lze však mít za to, že institut nepominutelného dědice má v našem právním řádu stále význam a jeho ochrana by neměla být opomíjena.

\section{6 Ústavněprávní a rodinněprávní aspekty povinného dílu}

Ve vztahu k dědickému právu je na ústavní úrovni řečeno jediné, a to: Dédèní se zaručuje. ${ }^{36}$ Toto zaručení dědění může být vykládáno několika zpo̊soby, jednak jako pokyn zákonodárci, aby upravil předpoklady a podmínky dědického práva. Na toto „zaručení dědění“ lze však také nahlížet jako na oprávnění nepominutelných dědiců (tak i ostatních dědiců), které je zůstavitel povinen respektovat, jak ve svém jednání inter vivos (dědická smlouva) tak v jednání mortis causa (povinný díl). ${ }^{37}$

Právo na povinný díl je dále možné odvodit i z čl. 32 LZPS který ř́ká, že Rodičovstvi a rodina jsou pod ochranou zákona. Zvláśtni ochrana dètí a mladistuých je zaručena. Ochrana rodiny plyne z významu rodiny jako základní a přirozené jednotky společnosti. ${ }^{38}$ Její ochrana a podpora se pak projevuje mimo jiné i v budování materiálních základů života rodiny a v právu na dědění. Je tak jisté, že povinný díl má i úzkou spojitost s právem rodinným, nebot' dle \855 občanského zákoníku mají rodiče a děti vưči sobě navzájem povinnosti a práva. Právu na povinný díl dítěte odpovídá povinnost rodiče mu tento povinný díl zanechat, přičemž této povinnosti se rodič nemůže vzdát. S ohledem na zásadu dobrých mravů však může být toto právo dítěte vyloučeno $\mathrm{v}$ důsledku porušení povinnosti dítěte dbát svých rodičů. Zákon v \855 rovněž stanovuje, že účelem práv a povinností, které mají rodiče vưči svým dětem, je zajištění morálního a hmotného prospěchu dítěte, což zanechání povinného dílu bezpochyby je. Opomenutí těchto blízkých osob, jako jsou děti, může být společností vnímáno jako něco nežádoucího, neobyyklého a nemorálního, odporujici obvyklým generačním vătabüm a požadavkưm generačni kontinuity. ${ }^{39}$

\footnotetext{
36 Čl. 11 Ústavního zákona č. 2/1993 Sb., Listina základních práv a svobod (dále jen LZPS).

37 HORÁK, Ondřej. Tzv. nepominutelný dědic v novém občanském zákoníku. Právní roz̧bledy, 2014, roč. 22, č. 11, s. 381-387.

38 KLÍMA, Karel a kol. Komentár k Ústavě a Listině. Plzeň: Aleš Čeněk, 2009, s. 660.

39 ELIÁŠ, Karel a kol. Nový občanský zákoník s aktualizovanou diovodovou zprávou. Ostrava: Sagit, 2012, s. $1285-1286$.
} 
Zvýšená ochrana dětí a mladistvých se projevuje především ve výši povinného dílu, která se odvijí od jejich (ne)zletilosti. Ačkoli tato úprava byla inspirována sovětským vzorem, přetrvala až dodnes. Nezletilý potomek má nárok na větší povinný díl, nebot' je většinou na zůstaviteli ještě finančně závislý, a společnost má zájem na jeho ochraně. Nezletilý potomek má však kromě většího povinného dílu v případě úmrtí rodiče, nárok na sirotčí důchod, ${ }^{40}$ popř́ípadě právo na výživu od druhého rodiče, což jej už tak zvýhodňuje oproti potomku zletilému. U zletilého potomka se sice předpokládá, že se o sebe dokáže sám postarat a zároveň už od zůstavitele za svůj život nějaký majetek dostal, tudíž pro něj otázka povinného dílu nemusí být až tak důležitá, je však toto opravdu důvod k tomu, aby jeho povinný díl byl menší než u nezletilého potomka, popřípadě byl úplně zrušen? Odpověd’ možná nabízí i úpravy inspiračních zdrojů (Rakousko, Německo, Švýcarsko), kde je výše povinného dílu stanovena bez ohledu na věk potomků, a to jednoduše proto, že věk by v tomto případě neměl hrát žádnou roli. Je jisté, že povinný díl do jisté míry omezuje vůli zůstavitele, zůstavitel se však rovněž sám mohl rozhodnout o tom, zda bude mít potomky, a pokud je už jednou má, měl by na to brát ohled, a to ne jenom do jejich zletilosti.

Pokud však má být výše povinného dílu od něčeho odvíjena, mělo by se jednat spíše o nabytí plné svéprávnosti než zletilosti, nebot' plné svéprávnosti může člověk nabýt i dř́ve než v 18 letech, a to z důvodu uzavření manželství, či přiznáním plné svéprávnosti. ${ }^{41} \mathrm{~V}$ těchto př́padech potomek pravděpodobně již nebude na zůstaviteli tak finančně závislý, aby to odůvodňovalo jeho právo na vyšší povinný díl. $\mathrm{Na}$ druhou stranu však může dojít u potomka k omezení ve svéprávnosti po dovršení 18 let, což může potvrdit (nejen) finanční závislost potomka na zůstaviteli. V takovém př́ípadě by právo na vyšší povinný díl bylo zcela odůvodnitelné.

\section{Rozšíření pojmu nepominutelného dědice na další osoby?}

Je zcela bez pochyb, že mimo děti je dalším nejbližším člověkem zůstavitele jeho manžel či manželka (popř́padě registrovaný partner). Proto se již za účinnosti ABGB diskutovalo o tom, zda by stejná ochrana jako je poskytována potomkům (v té době i rodičům), neměla být poskytována i manželce. ${ }^{42}$ Diskuze pokračovaly i v rámci př́ípravy vládního návrhu z roku 1937, nakonec však byla převzata úprava z obecného zákoníku občanského, obsahující právo manžela na zaopatření, a povinný díl manžela byl poté shledán jako nadbytečným. ${ }^{43} \mathrm{I}$ další občanské zákoníky se zabývaly tím, zda do nepominutelných

40 『52-53 zákona č. 155/1955 Sb., o důchodovém pojištění.

41 \30 občanského zákoníku.

42 Zejména vdova měla by míti nárok nepominutelný. SVOBODA, Emil. Dédické právo. Praha: Československý kompas, 1946, s. 9.

43 Dîvodová zpráva ke vládnímu návrbu občanského zákoníku z roku 1937. Komentár ke blavě 21 (』574 až 601). Dostupné na <http://senat.cz/informace/z_historie/tisky/4Vo/tisky/T0425_24.htm>. 
dědiců zahrnout i manžela zůstavitele. V občanském zákoníku 1950 zdůvodnily jeho nezahrnutí tak, že je o jeho potřeby postaráno novým právem rodinným, zejména institutem zákonného majetkového společenství. ${ }^{44} \mathrm{~K}$ jeho zahrnutí mezi nepominutelné dědice oproti úpravám v inspiračních zdrojích (Rakousko) tak nikdy nedošlo. ${ }^{45}$ Důvody proč nebyl manžel zahrnut ani do současné úpravy nepominutelných dědiců je jeho zajištění ze společného jmění manželů, dále prostřednictvím vdovského důchodu, a nově i prostřrednictvím práva některých osob na zaopatření. Společné jmění manželů však pro manžela nemusí představovat dostatečnou záruku zajištění po smrti manžela, vdovský důchod může být také jen dočasným řešením. Další forma zaopatření vyplývající z \1666 občanského zákoníku, spočívající ve slušné výživě z pozůstalosti po dobu šesti týdnů po smrti manžela, je pak v praxi zcela nevyužitelná. ${ }^{46}$ Zavedení povinného dílu manžela by tak do budoucna mohlo být ještě předmětem diskuzí.

\section{Závěr}

Z výše uvedeného je patrné, že institut nepominutelného dědice je odůvodněnou součástí našeho právního řádu, ačkoliv se jeho obsah na našem území neustále vyvijí. Jeho zrušení by bylo popřením ne jenom historického vývoje, ale také ústavně zaručených práv na dědění a ve výsledku i rodinně právních zásad vưbec. Dále by se jeho vyloučení neblaze projevilo i v rámci sociálního systému, nebot' by byla přenesena odpovědnost za budoucnost dítěte na stát (zvláště u potomků, kteří jsou na zůstaviteli finančně závis1i). Do budoucna by se tak místo řešení zda institut nepominutelného dědice ještě zachovat, mělo spíš řešit, jak tento institut zachovat, aby odpovídal potřebám společnosti a zároveň nebyl pouhým formálním právem těchto osob. Inspirací pro nás do budoucna může být nová úprava dědického práva v Rakousku, která se institutem nepominutelného dědice podrobně zaobírá a snaží se jej co nejvíc zmodernizovat pro současné potřeby společnosti. ${ }^{47}$

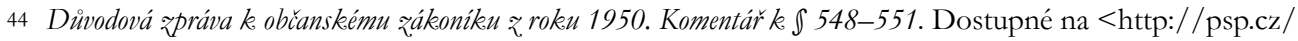
eknih/1948ns/tisky/t0509_17.htm>.

45 Je třeba však podotknout, že právní úprava Rakouska nemá zakotvený institut společného jmění manželů.

46 Viz TALANDA, Adam, TALANDOVÁ Iveta. Právo některých osob na zaopatrení. Acta Iuridica Olomucensia. (v tisku).

47 Erbrechts-Änderungsgesetz 2015, BGB I 2015/87. Dostupné na <https://www.ris.bka.gv.at/Dokumente/BgblAuth/BGBLA_2015_I_87/BGBLA_2015_I_87.html>; RONOVSKÁ, Kateřina, DOBROVOLNÁ, E. Nové rakouské dědické právo - rozhovor s prof. Dr. Martinem Schauerem. Bulletin advokacie, 2014, č. 4, s. 69-70. 